\title{
Exchange Rate and Economic Performance - A Comparative Study of Developed and Developing Countries
}

\author{
${ }^{1}$ Zohaib Aslam, ${ }^{2}$ Qaisar Ali Malik \\ ${ }^{I}$ FURC, Department of Business \& Economics. \\ ${ }^{2}$ Assistant Professor, FURC, Department of Business \& Economics.
}

\begin{abstract}
The most significant and crucial goal of the developing and developed countries is to attain continued economic and financial growth and stability through stock market performance. The aim of the present research is to analyze the impact of the changes in foreign exchange rates on economic performance of developed and developing economies measured by the changes in the stock market returns. The study is focused to explore whether and to what extent foreign exchange rates affect the economic performance as measured by the stock market returns. The significance of the study is evident from the fact that the portfolio managers and investors are usually interested in making prudent investment decisions so as to maximize their returns through keeping an eye on various domestic and international factors affecting their returns. Moreover developed and developing countries are also interested in stabilizing and enhancing the economic growth by monitoring and controlling the factors affecting such growth. The study considered the variables from Pakistani and Japanese markets to see whether the studied variables have any explanatory relationship that may help in formulating policies to enhance and stabilize economic growth. The study took 10 years monthly data related to stock prices of KSE 100 index and NIKKEI 225 index as dependent variable, whereas monthly data of foreign exchange rates of Pakistan and Japan are taken as independent variable. The study used descriptive and inferential statistics to identify and measure the relationship between foreign exchange rates and economic performance. The results depicted that foreign exchange rate is negatively associated to stock market returns and that the exchange rate is an insignificant predictor of stock market returns in case of Pakistani market hence the changes in foreign exchange rate were found to have no effect on economic performance as measured by the stock market returns. In case of Japan foreign exchange rate was found significantly and positively affecting stock market returns and that the changes in foreign exchange rate will also cause changes in stock market returns with an increase in exchange rate causing an increase in economic performance and a decrease in exchange rate causing a decrease in economic performance.
\end{abstract}

Keywords: Stock Returns, Economic Performance, NIKKEI 225, KSE 100

\section{Introduction}

The most significant and crucial goal of the developing and developed countries is to attain continued economic and financial growth and stability. The economic growth and stability depends upon the country's financial system. The importance of stock market performance for economic and financial growth has become more important after global financial crises, when all the world stock markets experienced severe down turn owing to the period of the global financial crisis. The crisis that was deemed as the most severe global financial crunch by most of the economists after the great depression faced in 1930 lead to the risk of complete crumple down of larger financial institutions, the guarantees of the banks by the governments, and the slumps in the stock markets across the world. It adversely affected the economic growth rate of many Asian countries experiencing negative returns during this financial crunch.

Capital market of Pakistan represented by Karachi stock exchange being one of the largest stock markets of Asia owing to its market capitalization and trading volume, has also been affected due to the changes in various macroeconomic indicators as affected by global financial crisis. The aim of the present research is to analyze the relationship between foreign exchange rates with stock market return, to explore whether and to what extent foreign exchange rates affect the stock market returns. The study examines the impact of foreign exchange rates on stock prices. The increase in foreign exchange rate leads to decrease in local currency value or deprecates the local home land currency; the deprecation of local currency affects the stock returns. So the adverse effects on stock returns may be prevented by controlling foreign exchange rates. The significance of the study is evident from the fact that the portfolio managers and investors are usually interested in making prudent investment decisions so as to maximize their returns. In this regard they have to keep an eye on various domestic and international factors affecting their returns. Thus the benefits investors may achieve through international diversification of portfolio have to be carefully explored and analyzed by closely monitoring the deviations in foreign exchange rates. Moreover the relationship between exchange rates movements and stock prices movements has to be understood. 
The study attempts to provide with some empirical evidence about how changes in exchange rates affect the stock returns. For this purpose developed and developing economies have been taken to identify the nature and extent of relationship, moreover to see whether the studied variables behave differently or in similar way in developed and developing economies.

\section{Literature Review}

Aggarwal (1981) investigated the effect of changes in exchange rates on the stock prices of USA. The study used floating rate monthly data of 4 years from 1974 to 1978 for conducting the analysis. The results of the study found that there is a positive and significant relationship between US stock returns and the US exchange rates. Solnik (1987) studied and investigated the influence of economic variables including interest rates, foreign exchange rates and the changes in inflation rates on stock exchange. For this analysis the study used western countries with monthly data. The results of the research study found that there is an insignificant but positive relationship between the variables studied. Hanniger (1988) investigated the relationship of exchange rate with stock prices, for this analysis the study used 7 years data starting from 1980 to 1986 . The research results found negative and significant relationship of exchange rate with stock prices.

Roll (1992) investigated the causal relationship between foreign exchange rate with stock prices. The study for the purpose of analysis used 4 years daily based data from 1988 to 1991. The results depicted that there is a positive causal linkage and association between foreign exchange rate and stock prices. Sohrabian (1992) investigated the relationship of exchange rate with stock prices. The study used Granger causality test for the analysis of the data collected on monthly basis covering years 1972 to 1988 . The results of the study depicted that there is no association over the long run between the studied variables. Mougouie (1996) investigated the influence of foreign exchange rate on stock prices, for the purpose of analysis the study used daily data of 8 countries, and the findings of the study showed that there is a positive significant influence of foreign exchange rates on stock prices. Murinde (1997) investigated the relationship between foreign exchange rates with stock prices in Asian countries including Pakistan. The study used 10 years monthly data starting from 1985 to 1994 for the purpose of analysis. The study found that there is no association over the long run between the studied variables. The study used co-integration data analysis technique to generalize the results. The same study found bidirectional relationship between the variables by using Granger causality test. Hamied (1998) investigated the association and linkage between the development of stock market and the growth of economy of twenty one emerging markets. The study used dynamic panel method to test the relationship and the results showed positive association and linkage between stock market performance and economic growth. Fok (1999) investigated the relationship of foreign exchange rates with stock prices. The study for the purpose of the analysis used Granger causality test to analyze the relationship between the variables. The results of the study showed that there is a significant but week relationship between the studied variables.

Nieh (2001) investigated the effect of exchange rate on stock prices for long run, for the analysis the study took daily data of four years. The results of the study showed that there is no long run relationship between the studied variables. Hatemi. (2002) investigated the relationship among exchange rate with stock returns and prices. For the analysis; five years monthly data was taken from 1992 to 1998 . The study used Granger causality analysis to generalize the results and findings. The study found unidirectional relationship among the studied variables. Rashied (2002) investigated the effect of foreign exchange rate with stock prices in Asian countries including Pakistan. The study used monthly data of 7 years starting from 1994 to 2000 for the analysis. The results of the study showed that here is unidirectional relationship of foreign exchange rate with stock prices over the long run. Aziz (2003) investigated the interaction of foreign exchange rate with stock prices, for the analysis the study used monthly data of 21 years ranging from 1977 to 1998 of Malaysian stock prices. For these long period observations the results of the study showed that there is a negative relationship between exchange rates and stock prices. Henry et al (2004) examined the relationship between stock returns and growth rates during the period of 1982-2001 by using switching regression method. The results of the study showed that Southeast Asian countries, that is, Korea, Hong Kong, Singapore and Philippines have a significant positive association and linkage between stock returns and economic growth. Kurihara (2006) investigated the relationship of foreign exchange rate with stock prices in Japan. For the purpose of analysis the study used 5 years daily based data of stock price and exchange rate. The results founds that there is significant relationship between the studied variables.

\section{Methodology}

The study addresses the issue regarding how variations in foreign exchange rates of developing and developed countries affect the stock market returns, moreover how the effect differ in developing countries as against developed countries and more specifically to measure the impact of foreign exchange rate on stock prices and the economic performance of the countries. The purpose of the study is to examine the relationship between the studied variables in Pakistani and Japanese markets to see whether exchange rates differences affect 
the stock prices and the economic performance of a developing and developed country. The study will augment the earlier literature by providing with the results helpful for the policy makers and the investors to diversify their portfolios accordingly.

The study took 10 years monthly data starting from January 2003 to December 2012 related to stock prices of KSE 100 index to represent developing country's stock market returns and NIKKEI 225 index to represent developed country's stock market returns. Stock market returns are taken as dependant variable. Similarly monthly data of foreign exchange rates of Pakistan and Japan were taken for the purpose of measuring the relationship between the studied variables. Foreign exchange rate is taken as independent variable for Pakistan and Japan market. On the basis of review of literature, following relationships have been assumed and developed for the purpose of testing and finalizing the results of the study. The relationships can be mathematically represented as:

For developing country; KSE $=\alpha_{1}+\beta_{1}$ GFOREX $+\varepsilon$; where KSE represents "Stock prices of Pakistan", $\alpha_{1}$ represents "Constant term", $\beta_{1}$ represents "Regression Coefficient" of "KSE to GFOREX", "GFOREX" is Log of foreign exchange rate and $\varepsilon$ represents "Error Term".

For developed country; NIKKEI $=\alpha_{1}+\beta_{1}$ GFOREX $+\varepsilon$; where NIKKEI represents "Stock prices of Japan", $\alpha_{1}$ represents "Constant term", $\beta_{1}$ represents "Regression Coefficient" of "NIKKEI to GFOREX", "GFOREX" is Log of foreign exchange rate and $\varepsilon$ represents "Error Term".

The study used descriptive and inferential statistics to identify and measure the relationship between foreign exchange rates and stock market returns representing economic performance. Mean, median and standard deviation are used for descriptive statistical analysis whereas Augmented Dickey Fuller test is used for data stationarity unit root test. Moreover correlation and regression are used to measure the impact of independent variable on dependant variable.

Descriptive Statistics

\section{Analysis \& Discussion}

\section{Statistical Data Summary (2003 to 2012)}

\begin{tabular}{|l|r|r|r|r|}
\hline \multirow{2}{*}{} & \multicolumn{2}{|c|}{$\begin{array}{c}\text { Pakistan - A developing } \\
\text { country of Asia }\end{array}$} & \multicolumn{2}{c|}{$\begin{array}{c}\text { Japan - A developed } \\
\text { country of Asia }\end{array}$} \\
\cline { 2 - 5 } & GFOREX & \multicolumn{1}{c|}{ KSE } & GFOREX & \multicolumn{1}{c|}{ NIKKEI } \\
\hline Mean & 0.004311 & 0.014742 & -0.00295 & 0.001566 \\
\hline Median & 0.001628 & 0.021767 & -0.00178 & 0.011928 \\
\hline Standard Deviation & 0.011075 & 0.08669 & 0.022253 & 0.075628 \\
\hline Minimum & -0.01259 & -0.37645 & -0.06402 & -0.46723 \\
\hline Maximum & 0.061707 & 0.17562 & 0.051793 & 0.141018 \\
\hline Count & 119 & 119 & 119 & 119 \\
\hline Source : Secondary data & \multicolumn{4}{|l}{} \\
\hline
\end{tabular}

The descriptive statistics support that for both foreign exchange rate and market returns, Pakistan market is performing better as against Japan market since the mean and median both values are higher for exchange rate and market returns of Pakistan as against Japan.

\section{Data Stationery Test}

Pakistan a Developing Country of Asia (2003 to 2012)

\begin{tabular}{|c|c|c|c|}
\hline \multicolumn{4}{|c|}{$\begin{array}{l}\text { Augmented Dickey-Fuller Unit Root Test } \\
\text { Test Conducted at Level }\end{array}$} \\
\hline Variable & Unit root assumptions & t-statistics & Probability \\
\hline \multirow[t]{3}{*}{ GFOREX } & Intercept & -4.9349 & 0.0001 \\
\hline & Trend \& Intercept & -5.0424 & 0.0003 \\
\hline & None & -3.3760 & 0.0009 \\
\hline \multirow[t]{3}{*}{ KSE } & Intercept & -10.0612 & 0.0000 \\
\hline & Trend \& Intercept & -10.1306 & 0.0000 \\
\hline & None & -9.77830 & 0.0000 \\
\hline
\end{tabular}

Unit root test using Augmented Dickey Fuller Unit Root Test conducted at level suggest the rejection of null hypothesis of presence of unit root, therefore the data of Pakistan is found to be stationary at the level. 


\section{Data Stationery Test}

Japan a Developed Country of Asia (2003 to 2012)

\begin{tabular}{|c|c|c|c|}
\hline \multicolumn{4}{|c|}{$\begin{array}{l}\text { Augmented Dickey-Fuller Unit Root Test } \\
\text { Test Conducted at Level }\end{array}$} \\
\hline Variable & Unit root assumptions & t-statistics & Probability \\
\hline \multirow[t]{3}{*}{ GFOREX } & Intercept & -9.0103 & 0.0000 \\
\hline & Trend \& Intercept & -5.8456 & 0.0000 \\
\hline & None & -8.9138 & 0.0000 \\
\hline \multirow[t]{3}{*}{ NIKKEI } & Intercept & -10.6311 & 0.0000 \\
\hline & Trend \& Intercept & -10.6360 & 0.0000 \\
\hline & None & -10.6725 & 0.0000 \\
\hline
\end{tabular}

Unit root test using Augmented Dickey Fuller Unit Root Test conducted at level suggest the rejection of null hypothesis of presence of unit root, therefore the data of Japan is also found to be stationary at the level.

\section{Correlation Analysis}

Pakistan a Developing Country of Asia (2003 to 2012)

\begin{tabular}{|l|l|l|}
\hline & KSE & GFOREX \\
\hline KSE & 1 & \\
\hline GFOREX & -0.1613 & 1 \\
\hline
\end{tabular}

The correlation analysis of Pakistani data showed that foreign exchange rate in Pakistan is negatively linked with market returns, hence an inverse relationship was found between the studied variables, therefore an increase in exchange rate will cause a decline in stock returns and the economic performance of the country and a decrease in exchange rate will cause an increase in stock returns and the economic performance of the country.

\section{Correlation Analysis}

\section{Japan a Developed Country of Asia} (2003 to 2012)

\begin{tabular}{|l|l|l|}
\hline & NIKKEI & GFOREX \\
\hline NIKKEI & 1 & \\
\hline GFOREX & 0.39257 & 1 \\
\hline
\end{tabular}

The correlation analysis of Japanese data showed that foreign exchange rate in Japan is positively linked with market returns, hence a direct relationship was found between the studied variables, therefore an increase in exchange rate will cause an increase in stock returns and the economic performance of the country and a decrease in exchange rate will cause a decrease in stock returns and the economic performance of the country.

\begin{tabular}{|c|c|c|c|c|}
\hline \multicolumn{5}{|c|}{$\begin{array}{l}\text { Regression Analysis } \\
\text { Pakistan a Developing Country of Asia (2003 to 2012) } \\
\text { Dependent Variable: KSE } \\
\text { Method: Least Squares } \\
\text { Included observations: } 119\end{array}$} \\
\hline Variable & Coefficient & Std. Error & $\mathrm{t}$-Statistic & Prob. \\
\hline $\begin{array}{l}\mathrm{C} \\
\text { GFOREX }\end{array}$ & $\begin{array}{l}0.020186 \\
-1.262603\end{array}$ & $\begin{array}{l}0.008457 \\
0.714173\end{array}$ & $\begin{array}{l}2.386942 \\
-1.767925\end{array}$ & $\begin{array}{l}0.0186 \\
0.0797\end{array}$ \\
\hline $\begin{array}{l}\text { R-squared } \\
\text { Adjusted R-squared } \\
\text { S.E. of regression } \\
\text { Sum squared resid } \\
\text { Log likelihood } \\
\text { F-statistic } \\
\text { Prob(F-statistic) }\end{array}$ & $\begin{array}{l}0.026019 \\
0.017694 \\
0.085920 \\
0.863717 \\
124.2215 \\
3.125558 \\
0.079680\end{array}$ & \multicolumn{2}{|c|}{$\begin{array}{l}\text { Mean dependent var } \\
\text { S.D. dependent var } \\
\text { Akaike info criterion } \\
\text { Schwarz criterion } \\
\text { Hannan-Quinn criter. } \\
\text { Durbin-Watson stat }\end{array}$} & $\begin{array}{l}0.014742 \\
0.086690 \\
-2.054144 \\
-2.007436 \\
-2.035177 \\
1.846350\end{array}$ \\
\hline
\end{tabular}

The regression result for Pakistani data depicts that foreign exchange rate is negatively associated to stock market returns. The significance value of $t$ statistics tell that the exchange rate is an insignificant predictor of stock market returns in case of Pakistani market, and the model is not fit for generalizing and interpreting the 
results, hence it may be generalized that the changes in foreign exchange rate will cause no change to stock market returns in case of Pakistan.

\author{
Regression Analysis \\ Japan a Developed Country of Asia (2003 to 2012) \\ Dependent Variable: NIKKEI \\ Method: Least Squares \\ Included observations: 119
}

\begin{tabular}{lcccc}
\hline \hline Variable & Coefficient & Std. Error & t-Statistic & Prob. \\
\hline \hline C & 0.005502 & 0.006460 & 0.851651 & 0.3961 \\
GFOREX & 1.334192 & 0.288978 & 4.616933 & 0.0000 \\
\hline \hline & & & \\
R-squared & 0.154111 & Mean dependent var & 0.001566 \\
Adjusted R-squared & 0.146881 & S.D. dependent var & 0.075628 \\
S.E. of regression & 0.069854 & Akaike info criterion & -2.468167 \\
Sum squared resid & 0.570904 & Schwarz criterion & -2.421459 \\
Log likelihood & 148.8560 & Hannan-Quinn criter. & -2.449201 \\
F-statistic & 21.31607 & Durbin-Watson stat & 1.992813 \\
Prob(F-statistic) & 0.000010 & & \\
\hline \hline
\end{tabular}

The regression result for Japanese data depicts that foreign exchange rate is significantly and positively associated to stock market returns. The significance value of $t$ statistics tell that the exchange rate is a significant predictor of stock market returns in case of Japanese market, and the model is fit for generalizing and interpreting the results, hence it may be generalized that the changes in foreign exchange rate will also cause changes in stock market returns in case of Japan. Hence an increase in exchange rate will cause an increase in stock returns and economic performance of Japan and a decrease in exchange rate will cause a decrease in stock returns and the economic performance of Japan. Value of $\mathrm{R}^{2}$ tells that almost $15 \%$ of the variation in stock returns is explained by the changes in foreign exchange rates.

\title{
V. Conclusion
}

The study found positive and significant relationship between variables that means change in foreign exchange rate has impact on Japan market return for long run, because Japan is a developed country and most of developed countries keep foreign exchange rate low to increase their export and encourage foreign investors that's why a little change in foreign exchange rate has affect on market return for short run or for long run. But in Pakistan a developing country the study found negative and insignificant relationship between foreign exchange rate and Market return that is there is no effect of change in foreign exchange rate on stock prices in the long run. The increase in foreign exchange rate depreciates the local home land currency, which results in lesser buying power of home land currency. It encourages the foreign investors because the stock prices decreases for them which becomes a big risk for the local investor resulting in an increase in the uncertainty in stock market leading to the instability in economic and financial performance of the country. It also decreases the exports of Pakistan adversely affecting the economy, hence Pakistani Government should take active measures to monitor and control the increase in foreign exchange rate to stabilize the economic performance of the country. 


\section{References}

[1] Aggarwal (1981), Exchange rates and stock prices, a study of United States capital market floating exchange rates, Akron Business \& Economic Review, pp7-12.

[2] Aziz (2003), Macro economic variables and the Malaysian equity market of Asia, Journal of Economic Studies, pp 5-28.

[3] Fok (2007), Dynamic linkages between exchange rates and stock prices, International Review of Economics and Finance, pp 502521.

[4] Gujarati (2003), Basic Econometrics, McGraw Hill, India.

[5] He, J (1998), The foreign exchange exposure of Japan multinational corporations, Journal of Finance, pp $732-754$.

[6] Henery (2000), Do market liberalization cause investment booms, Journal of Finance \& Economics, pp 301-333.

[7] Hogan (1998), The pricing of country funds obtained from emerging markets, International Journal of Applied Finance, pp 110-144.

[8] International Monetary Fund, www.IMF.com.pk

[9] Johasen (1988), The statistical analysis of co-integration vectors, The Journal of Economic and Dynamic Control, pp 230-255.

[10] Keurihara (2006), The relationship between exchange rate and stock prices of Japan, International Journal of Business and Economics, pp 374-385.

[11] Mougiue (1996), On the dynamic relationship between stock prices and exchange rates, Journal of Financial Research, pp $192-206$

[12] Murinde (1997), Exchange rates and stock prices interactions in emerging financial markets, Applied Financial Economics, pp24-35.

[13] Nieh, C. (2001), Dynamic relationship between exchange rates and stock prices, Review of Finance and Economics, 478-491.

[14] Rasheid (2002), Stock prices and exchange rates, are the related ?, The Pakistan Development Review, pp 534-551.

[15] Roll (1983), The fiscal and monetary linkage between exchange rate and stock returns, Journal of Finance \& Economics, pp1-33.

[16] Sohraban (1992), Stock prices and effective exchange rate, Applied Economics, pp460-465.

[17] Solnik (1987), Using financial prices to test exchange rate models in western countries, Journal of Finance \& Economics, pp 41 - 49. 